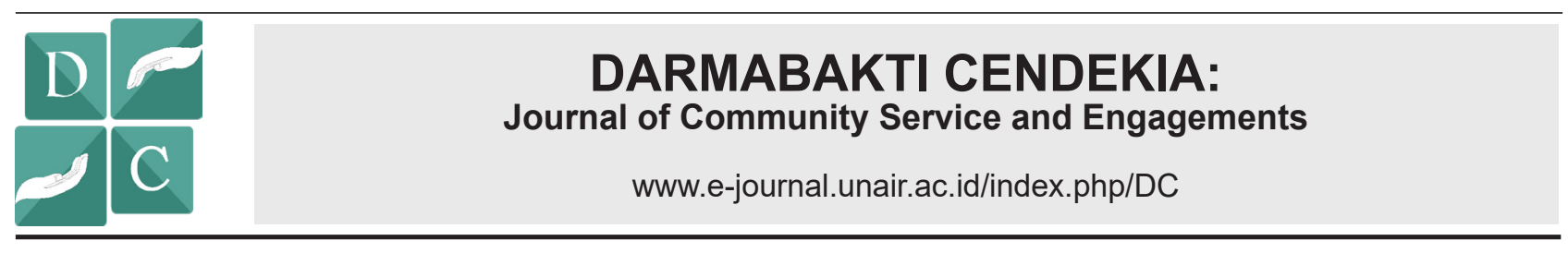

\section{BOLUS TEMULAWAK IMPLEMENTATION ON BEEF CATTLE IN SELOGABUS VILLAGE, PARENGAN, TUBAN REGENCY}

\author{
APLIKASI BOLUS TEMULAWAK PADA SAPI POTONG DI DESA \\ SELOGABUS KECAMATAN PARENGAN KABUPATEN TUBAN
}

Scope:

Applied Science

\author{
Siti Eliana Rochmi ${ }^{1,3}$ 國 Retno Sri Wahjuni ${ }^{1,2}$, Miyayu Soneta Sofyan 1 回 \\ ${ }^{1}$ Study Program of Veterinary Paramedic, Department of Health, Faculty of Vocational Studies, Universitas Airlangga, Surabaya-Indonesia \\ ${ }^{2}$ Department of Basic Medical Sciences, Faculty of Veterinary Medicine, Universitas Airlangga, Surabaya-Indonesia \\ ${ }^{3}$ Doctoral Student of Veterinary Science, Faculty of Veterinary Medicine, Universitas Airlangga, Surabaya-Indonesia
}

\section{$A B S T R A C T$}

Background: The beef cattle farming in Tuban area is mostly on a small scale and traditionally maintained. In general, the nutritional adequacy of the animal feed provided is not optimal, while the potential for livestock in the area is quite large. There are still few breeders who provide concentrates on the grounds that the high costs incurred so that the weight growth of beef cattle is still not optimal. Bolus Temulawak is an animal feed substitute for concentrate with temulawak as an additive. Objective: This activity aims to strengthen the economy of beef cattle farmers through the introduction, dissemination, and transfer of temulawak bolus technology as an alternative feed with sufficient nutritional value for beef cattle so that daily weight gain can be maximized. Methods: This activity held towards community empowerment such as coaching related to feed and livestock health by FGD (Focus Group Discussion) followed by training on making Bolus Temulawak and application of Bolus Temulawak to beef cattle. Evaluation of this activity is pre and post test of community service participants, as well as body weight measurement of beef cattle before and after being given Bolus Temulawak. Results: The results of this community service are an increase in daily body weight of beef cattle, as well as an increase in the knowledge and skills of community service participants. Conclusion: Community service activities have a positive impact on the development of beef cattle farms in partner areas.

\section{$A B S T R A K$}

\begin{abstract}
Latar belakang: Pemeliharaan sapi potong di wilayah Tuban sebagian besar masih berskala kecil dengan skala peternakan rakyat. Secara umum, kecukupan gizi pakan ternak yang diberikan belum optimal sedangkan potensi ternak di daerah tersebut cukup besar. Masih sedikit peternak yang memberikan konsentrat dengan alasan tingginya biaya yang dikeluarkan sehingga pertumbuhan berat badan sapi potong masih belum optimal. Bolus Temulawak merupakan pakan ternak pengganti konsentrat dengan temulawak sebagai zat aditifnya. Tujuan: Kegiatan ini bertujuan untuk penguatan ekonomi peternak sapi potong melalui pengenalan, penyebarluasan, dan transfer teknologi bolus temulawak sebagai pakan alternatif dengan nilai gizi yang cukup untuk ternak sapi potong sehingga pertambahan berat badan harian dapat maksimal. Metode: Kegiatan ini dilaksanakan ke arah pemberdayaan masyarakat seperti pembinaan terkait pakan dan kesehatan ternak secara FGD (Focus Group Discussion) dilanjutkan pelatihan pembuatan Bolus Temulawak dan aplikasi Bolus Temulawak terhadap sapi percontohan. Evaluasi kegiatan ini adalah pre dan post test peserta pengmas, serta pengukuran berat badan sapi potong sebelum dan setelah diberi Bolus temulawak. Hasil: Hasil dari pengmas ini adalah adanya peningkatan berat badan sapi potong harian, serta peningkatan pengetahuan dan ketrampilan peserta pengmas. Kesimpulan: Kegiatan Pengmas memberikan dampak yang positif terkait pengembangan peternakan sapi potong di wilayah mitra.
\end{abstract}

\section{$A R T I C L E$ IN FO}

Received 10 July 2020 Revised 23 December 2020 Accepted 14 April 2021 Online 28 June 2021

*Correspondence (Korespondensi): Siti Eliana Rochmi

E-mail: eliana.rochmi@vokasi.unair.ac.id

Keywords:

Animal feeding, Beef cattle, Curcuma zanthorrhiz

Kata kunci:

Pakan, Sapi potong,

Temulawak 


\section{PENDAHULUAN}

Peternakan rakyat sapi potong dikelola secara tradisional dan intensif di daerah pedesaan dengan sumber daya terbatas sehingga rentan terhadap berbagai permasalahan. Salah satu permasalahan yang dihadapi peternak rakyat adalah pakan dan pengendalian penyakit. Pada usaha peternakan tradisional, pemberian pakan berkualitas masih jarang dilakukan (Harsita \& Amam, 2019). Pakan yang diberikan pada peternakan tradisional umumnya mempunyai nilai nutrisi rendah seperti rumput segar, daun segar, dan jerami padi (Rochmi \& Wahjuni, 2017). Rendahnya nutrisi pakan dapat menyebabkan kurang optimalnya produktifitas yang dihasilkan oleh ternak (Rochmi et al., 2020). Kecukupan pakan sapi potong dari segi kualitas dan kuantitas dapat diberikan dari hijauan serta konsentrat (Sandi et al., 2018).

Hijauan merupakan pakan utama ternak ruminansia yang merupakan sumber serat kasar dan umumnya diberikan dalam keadaan segar (Akoso, 2009). Selain itu, hijauan mengandung air, karbohidrat, protein, lemak, vitamin, dan mineral yang dibutuhkan dalam metabolisme ternak (Rasjid, 2012). Selain hijauan ternak juga membutuhkan konsentrat sebagai penunjang kebutuhan hidup pokok, pertumbuhan maupun reproduksi. Kecukupan makro maupun mikronutrien dari kombinasi hijauan dan konsentrat merupakan syarat utama pertumbuhan berat badan maupun kesehatan reproduksi yang optimal (Sari, 2014; Setiadi 2010). Ternak yang hanya diberikan hijauan dapat menyebabkan produksi yang tidak optimal tetapi biaya yang dibutuhkan lebih ekonomis, sedangkan ternak yang hanya diberikan konsentrat membutuhkan biaya lebih mahal dengan kemungkinan adanya gangguan pencernaan meskipun produksi yang tinggi dapat tercapai (Siregar, 2008). Pada peternakan rakyat, sebagian besar pakan yang diberikan hanya hijauan dengan diberikan dedak sebagai tambahanya sehingga kecukupan nutrisi belum terpenuhi. Keterbatasan modal dan tenaga kerja pada peternakan rakyat merupakan faktor utama ketidaktepatan pemberian pakan dari segi kualitas dan kuantitas sehingoga produktivitas ternak sulit tercapai (Hadi et al., 2002).

Bolus Temulawak Herbal adalah pakan pengganti konsentrat yang menggunakan bahan baku berbasis bahan lokal (limbah pertanian) dengan tambahan rimpang temulawak yang banyak tersedia di daerah. Temulawak terkenal mempunyai banyak manfaat dan khasiat diantaranya sebagai anthelmentik (Chuzaemi et al., 2020; Pramudita et al., 2013; Wahjuni \& Bijanti, 2006) anti mikroba (Mashita, 2014; Yusuf et al., 2009), penambah palatabilitas (Wati \& Yusuf,
2020) dan antioksidan. Rimpang temulawak mengandung bahan aktif kurkuminoid, xanthorrizol, dan minyak atsiri yang dapat meningkatkan produktivitas sapi potong.

Kegiatan Pengabdian pada Masyarakat ini dilakukan dengan pembinaan dan pelatihan pembuatan Bolus Temulawak Herbal berbasis bahan lokal dengan harapan dapat mengatasi masalah penyediaan pakan yang berkualitas dengan menggunakan bahan lokal.

\section{METODE}

Kegiatan PKM ini dilakukan di Desa Selogabus Kecamatan Parengan Kabupaten Tuban dengan metode Focus Group Discussion (FGD) meliputi pemberian materi pakan ternak, kesehatan ternak, dilanjutkan dengan pelatihan pembuatan Bolus Temulawak Herbal serta aplikasi Bolus Temulawak terhadap sapi percontohan. Kegiatan ini dilakukan mulai bulan Juli 2020.

Media yang digunakan dalam FGD adalah brosur yang berisi tentang materi-materi di atas. Sedangkan pelatihan pembuatan Bolus Temulawak Herbal membutuhkan bahan seperti dedak padi, empok jagung, mollases, mineral mix, dan serbuk temulawak. Peralatan yang digunakan adalah wajan, kompor, dan alat cetak Bolus Temulawak. Aplikasi UMB Herbal hasil pengmas diberikan kepada enam sapi percontohan dengan cara jilatan setiap pagi dan sore hari selama satu bulan.

Evalusi kegiatan PKM ini dilakukan dengan pengukuran pemahaman peserta melalui pre dan post kegiatan FGD. Pengukuran berat badan sapi potong percontohan dengan menggunakan metode pendugaan berat badan rumus Winter yang dilakukan pre dan post pemberian UMB Herbal selama satu bular (Santosa, 2009).

Keterangan :

$$
B B(\text { Pound })=\frac{L D^{2} \times P B(\text { inchi })}{300 L D^{2} \times P B}
$$

$$
\begin{aligned}
& \mathrm{BB}=\text { Bobot Badan } \\
& \mathrm{LD}=\text { Lingkar Dada } \\
& \mathrm{PB}=\text { Panjang Badan }
\end{aligned}
$$

Transformasi berat dan panjang adalah sebagai berikut:

1 pound $=0,45 \mathrm{~kg}$

$1 \mathrm{~cm} \quad=0,39$ inchi

$1 \mathrm{~kg}=2,20$ pound

1 inchi $=2,54 \mathrm{~cm}$

\section{HASIL DAN PEMBAHASAN}

Kegiatan pembinaan dan pelatihan pembuatan Bolus Temulawak di Desa Selogabus Kecamatan Parengan Kabupaten Tuban berjalan dengan baik 
dan lancar meskipun sempat terkendala pandemi Covid-19. Untuk mengantisipasi penyebaran Covid-19, pembinaan peserta dilakukan dengan FGD (Gambar 1) maupun pelatihan (Gambar 2) dengan menerapkan prokol kesehatan. Peserta PKM menyambut dengan baik dan herpartisipasi aktif dalam kegiatan tersebut. Pada Tabel 1 terlihat adanya peningkatan pemahaman dari peserta kegiatan dengan rata-rata pemahaman $80 \&$ untuk setiap topik. Peningkatan pemahaman materi dapat berdampak positif terhadap manajemen pemeliharaan sapi potong, penanganan kesehatan reproduksi dan pemanfaatan limbah pertanian menjadi pakan sapi potong yang berkualitas.

Tabel 1. Evaluasi pemahaman peternak

\begin{tabular}{|c|c|c|c|c|c|}
\hline \multirow{2}{*}{ No } & \multirow{2}{*}{ Indikator } & \multicolumn{2}{|c|}{$\begin{array}{c}\text { Pengetahuan / } \\
\text { Pemahaman Peserta } \\
\text { Sebelum PKM (\%) }\end{array}$} & \multicolumn{2}{|c|}{$\begin{array}{l}\text { Pengetahuan / Pemahaman } \\
\text { Peserta Setelah PKM (\%) }\end{array}$} \\
\hline & & $\begin{array}{l}\text { Tahu / } \\
\text { Paham } \\
(\%)\end{array}$ & $\begin{array}{c}\text { Belum tahu / } \\
\text { Belum Paham } \\
(\%)\end{array}$ & $\begin{array}{l}\text { Tahu / } \\
\text { Paham } \\
\text { (\%) }\end{array}$ & $\begin{array}{c}\text { Belum tahu / } \\
\text { Belum Paham } \\
(\%)\end{array}$ \\
\hline 1 & $\begin{array}{l}\text { Kebutuhan nutrisi pakan ternak sapi } \\
\text { potong }\end{array}$ & 25 & 75 & 100 & 0 \\
\hline 2 & $\begin{array}{l}\text { Limbah pertanian dapat digunakan } \\
\text { menjadi pakan ternak berkualitas }\end{array}$ & 5 & 95 & 100 & 0 \\
\hline 3 & $\begin{array}{l}\text { Pakan ternak mempengaruhi kesehatan } \\
\text { ternak }\end{array}$ & 5 & 95 & 95 & 5 \\
\hline 4 & $\begin{array}{l}\text { Bolus Temulawak sebagai pengganti } \\
\text { konsentrat }\end{array}$ & 0 & 100 & 100 & 0 \\
\hline 5 & Manfaat temulawak untuk sapi potong & 30 & 70 & 100 & 0 \\
\hline 6 & $\begin{array}{l}\text { Penggunaan temulawak untuk obat- } \\
\text { obatan ternak }\end{array}$ & 35 & 65 & 100 & 0 \\
\hline 7 & Pakan utama ternak sapi potong & 5 & 95 & 100 & 0 \\
\hline 8 & Pakan mempengaruhi reproduksi ternak & 15 & 25 & 95 & 5 \\
\hline 9 & Tanda-tanda birahi pada ternak & 20 & 80 & 100 & 0 \\
\hline
\end{tabular}

Tabel 2. Pemberian Bolus Temulawak terhadap rataan bobot badan dan pertambahan bobot badan harian (pbbh) ternak sapi potong

\begin{tabular}{cccccc}
\hline No & $\begin{array}{c}\text { Kode } \\
\text { Ternak }\end{array}$ & $\begin{array}{c}\text { Bobot Awal (kg) } \\
\text { (pre pemberian Bolus } \\
\text { Temulawak) }\end{array}$ & $\begin{array}{c}\text { Bobot Akhir (kg) } \\
\text { (post pemberian Bolus } \\
\text { Temulawak) }\end{array}$ & $\begin{array}{c}\text { Pertambahan BB } \\
\text { (kg/ekor) selama } \\
\text { 30 hari }\end{array}$ & $\begin{array}{c}\text { Rataan Pertambahan } \\
\text { bobot badan harian } \\
\text { (kg/ekor/hari) }\end{array}$ \\
\hline 1 & $\mathrm{a}$ & 172,80 & 197,42 & 24,62 & 0,82 \\
2 & $\mathrm{~b}$ & 148,69 & 175,35 & 26,66 & 0,89 \\
3 & $\mathrm{C}$ & 179,64 & 201,58 & 21,94 & 0,73 \\
4 & $\mathrm{~d}$ & 294,17 & 321,45 & 27,28 & 0,91 \\
5 & $\mathrm{e}$ & 273,19 & 300,75 & 27,56 & 0,92 \\
6 & $\mathrm{f}$ & 252,34 & 279,03 & 26,69 & 0,88 \\
\hline \multicolumn{7}{l}{ Rata-rata pertambahan berat badan kg/ekor/hari } \\
\hline
\end{tabular}




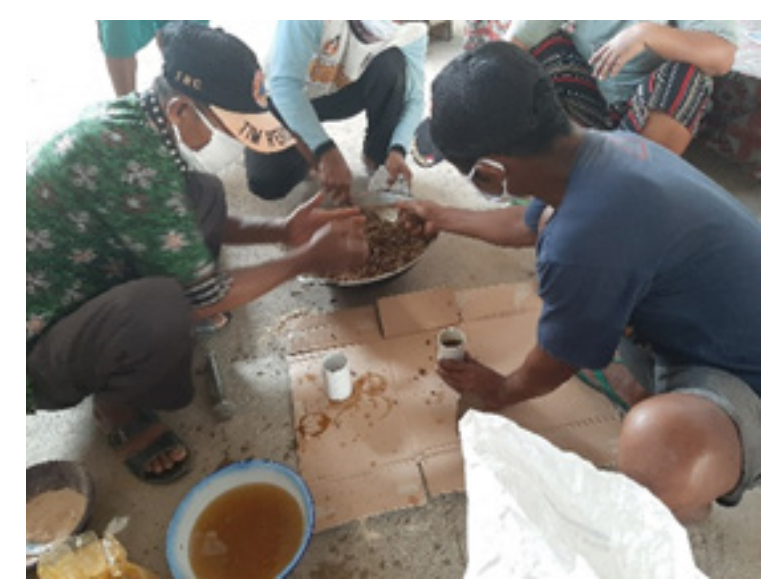

Gambar 2. Pelatihan Pembuatan Bolus Temulawak

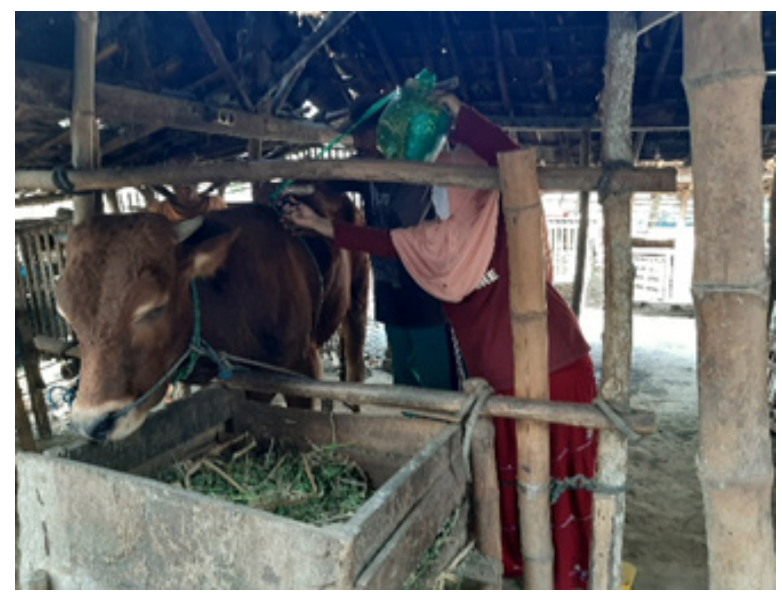

Gambar 3. Monitoring Evaluasi Aplikasi Bolus Temulawak pada Ternak Percontohan

Hasil dariaplikasi Bolus Temulawakpada ternak percontohan dapat meningkatkan pertambahan berat badan(Tabel 2). Penilaian pertambahan berat badan sapi potong dilakukan melalui monitoring evaluasi pada ternak percontohan (Gambar 3). Pada Tabel 2 menunjukkan pertambahan berat badan dengan kisaran 0,73 kg/ekor/hari - 0,92 kg/ ekor/hari dengan rerata 0,85 kg/ekor/hari. Pada Bolus Temulawak terdapat kandungan tetes atau molasees sebagai peningkat nafsu makan ternak. Molasses merupakan bahan sumber energy terlarut untuk mikroba rumen sehingga berkolerasi positif terhadap metabolisme ternak (Chuzaemi et al., 2020). Aplikasi penggunaan UMB herbal tersebut adalah dengan cara jilatan sehingga $\mathrm{pH}$ rumen terjaga stabilitasnya Rochmi et al., 2018). $\mathrm{pH}$ rumen yang terjaga dapan meningkatkan pertumbuhan dan aktifitas mikroba rumen pada ternak sehingga dapat meningkatkan konsumsi hijauan/pakan sumber serat kasar (De \& Singh, 2002). Mutu, jumlah pakan dan pemberian mempengaruhi kemampuan produksi sapi potong. Kombinasi pakan hijauan dan konsentrat pada ternak sapi potong dapat meningkatkan pertambahan berat badan dengan waktu penggemukan yang relative singkat dikarenakan tercukupinya nilai nutrien dan kemudahan pakan untuk dicerna (Mappanganro et al., 2018; Setiadi, 2001). Bolus Temulawak adalah pakan pengganti konsentrat yang mempunyai kualitas baik.

\section{KESIMPULAN DAN SARAN}

Kegiatan pembinaan dan pelatihan pembuatan Bolus Temulawak di Desa Selogabus sangat bermanfaat bagi masyarakat peternak dalam mengatasi permasalahan pakan yang berkualitas baik. Diharapkan pula pelatihan semacam ini dapat dilakukan di wilayah Desa lain untuk menunjang swasembada daging.

\section{UCAPAN TERIMA KASIH}

Penulis mengucapkan terima kasih banyak kepada Pemerintah Desa Selogabus yang telah mengizinkan dan bersedia menjadi mitra dari program pengabdian kepada masyarakat ini. Penulis juga mengucapkan terima kasih kepada Rektor Universitas Airlangga dan Dekan Fakultas Vokasi Universitas Airlangga yang telah membiayai kegiatan ini. Penulis menyatakan tidak ada konflik kepentingan dengan pihak-pihak yang terkait dalam kegiatan pengabdian kepada masyarakat ini.

\section{DAFTAR PUSTAKA}

Akoso, B.T. 2009. Epidemiologi dan Pengendalian Antraks. Yogyakarta : Penerbit Kanisius.

Chuzaemi, S., et al. 2020. UMMB Temulawak (Curcuma Xanthorrhiza) Sebagai Suplemen Pakan Ternak Ruminansia. Jurnal Nutrisi Ternak Tropis Vol. 3(1). Pp. 23-29.

De, D., \& Singh G.P. 2002. Monensin Enriched Urea Molasses Mineral Block on Feed Intake, Nutrient Digestibility and Blood Glucose in Cattle Fed on Wheat Straw Based Diet. AsianAustralasian Journal of Animal Sciences Vol. 15(11). Pp. 1579-1584.

Hadi, P.U., et al. 2002. A Progress report summary: analytic framework to facilitate development of Indonesia's beef industry. Paper Presented at the "Routine Seminar". Center for Agro Socio Economic Research and Development. Bogor, 8 Maret 2002. 24 p.

Harsita, P.A. \& Amam. 2019. Permasalahan Utama Usaha Ternak Sapi Potong di Tingkat Peternak dengan Pendekatan Vilfredo Pareto Analysis. Prosiding Seminar Nasional Teknologi Peternakan dan Veteriner; Jember, Indonesia. Pp. 241-250. 
Mappanganro, R., et al. 2018. Pengaruh Pemberian Alga Coklat (Sargassum sp.) Terhadap Pertambahan Berat Badan Sapi Bali Jantan. Jurnal Ilmu dan Industri Peternakan Vol. 4(2). Pp. 139-148.

Mashita, A.R. 2014. Efek Antimikroba Ekstrak Rimpang Temulawak (Curcuma xanthorrhiza) Terhadap Pertumbuhan Staphylococcus aureus. Santika Medika: Jurnal Ilmu Kesehatan dan Kedokteran Keluarga Vol. 10(2). Pp. 138144.

Pramudita, F.E., Trisunuwati, P., \& Indrati, R. 2013. Pengaruh Pemberian Serbuk Ekstrak Temu Hitam (Curcuma aeruginosa ) dan Temu Lawak (Curcuma xanthorrhiza) sebagai Antelmentika Heterakis gallinarum pada Ayam Petelur. Retrived from https://fkh.ub.ac. id/wp-content/uploads/2012/10/3.-Fisma-EkaPramudita.pdf

Rasjid, S. 2012. The Great Ruminant Nutrisi, Pakan, dan Manajemen Produksi. Cetakan Kedua. Surabaya: Brilian Internasional.

Rochmi, S.E. \& Wahjuni, R.S. 2017. Teknologi Complete Feed Herbal Untuk Peningkatan Produktivitas Sapi Potong Di Kecamatan Parengan Kabupaten Tuban. Jurnal Agro Veteriner Vol. 6(1). Pp. 1-8.

Rochmi, S.E., Wahjuni, R.S., \& Achmad, A.B. 2018. Pemberian Dodol Temulawak Terhadap Pertambahan Berat Badan Dan Infestasi Cacing Saluran Pencernaan Pada Sapi Potong Di Desa Brangkal Dan Desa Cengkong Kecamatan Parengan Kabupaten Tuban. Jurnal Agro Veteriner Vol. 7(1). Pp. 25-30.

Rochmi, S.E., et al. 2020. Pelatihan Pembuatan Umb Herbal Di Kecamatan Parengan Kabupaten Tuban. Darmabakti Cendekia: Journal of Community Service and Engagements Vol. 2(1). Pp. 15-19.
Sandi, S., M. Desiarni, \& Asmak. 2018. Manajemen Pakan Ternak Sapi Potong di Peternakan Rakyat di Desa Sejaro Sakti Kecamatan Indralaya Kabupaten Ogan Ilir. Jurnal Peternakan Sriwijaya Vol. 7(1). Pp. 21-29.

Santosa, U. 2009. Mengelola Peternakan Sapi Secara Profesional. Jakarta: Penebar Swadaya.

Sari, I.K. 2014. Prevalensi Dan Derajat Infeksi Cacing Saluran Pencernaan Pada Sapi Peranakan Ongole (PO) Dan Limousin Di Kecamatan Tikung Kabupaten Lamongan. Skripsi. Surabaya: Sarjana Universitas Airlangga.

Setiadi, B. 2010. Beternak Sapi Pedaging dan Masalahnya. Semarang: Aneka Ilmu.

Siregar. 2008. Ransum Ternak Ruminansia. Jakarta: Penebar Swadaya.

Wahjuni, R.S., \& Bijanti, R. 2006. Uji Efek Samping Formula Pakan Komplit terhadap Fungsi Hati dan Ginjal Pedet Sapi Friesien Holstein. Media Kedokteran Hewan Vol. 22(3). Pp. 174-179.

Wati, N.E. \& Yusuf, M. 2020. Pengaruh Penambahan Tepung Temulawak (Curcuma xanthoriza) dalam Ransum Terhadap Efisiensi Pakan Sapi Peranakan Simmental. Jurnal Wahana Peternakan Vol. 4(1). Pp. 1-5.

Yusuf, N. A., et al. 2009. Antibacterial Activities of Curcuma Xanthorrhiza Roxb and Its Related Species. Proceedings of the First International Symposium on Temulawak; Bogor, Indonesia. Pp. 213-216. 